\title{
The use of monoclonal antibodies for the treatment of epithelial ovarian cancer (Review)
}

\author{
ANGÈLE L.M. OEI ${ }^{1}$, FRED C.G.J. SWEEP ${ }^{2}$, CHRIS M.G. THOMAS ${ }^{1,2}$, \\ OTTO C. BOERMAN $^{3}$ and LEON F.A.G. MASSUGER ${ }^{1}$
}

\begin{abstract}
Departments of ${ }^{1}$ Obstetrics and Gynaecology, ${ }^{2}$ Chemical Endocrinology and ${ }^{3}$ Nuclear Medicine,
\end{abstract} Radboud University Nijmegen Medical Centre, P.O. Box 9101, 6500 HB Nijmegen, The Netherlands

Received October 30, 2007; Accepted December 28, 2007

\begin{abstract}
The prognosis for patients with ovarian cancer is still poor and more effective therapeutic modalities are needed. (Radio)immunotherapy using monoclonal antibodies (Mabs) could be one of these approaches. Here, we review the status of (radio)immunotherapy using Mabs for the treatment of ovarian cancer. The Pubmed database was searched for clinical trials investigating the effect of (radio)immunotherapy in ovarian cancer published until October 1, 2007. Keywords for the search were: ovarian cancer, monoclonal antibodies, CA 125, gp38, HER2, HMFG, MUC1, TAG 72 and VEGF. A total of 44 trials on immunotherapy with unconjugated Mabs, Mab vaccination and (radio)immunotherapy directed towards the antigens CA 125, gp38, HER2, MUC1, TAG 72 or VEGF in patients with ovarian cancer were found, reviewed and discussed. Out of these trials, 23 studied immunotherapy with unconjugated Mabs, 5 vaccination with Mabs and 16 trials studied (radio)immunotherapy. The lack of large randomized prospective trials with Mabs directed to tumor-associated antigens expressed on ovarian cancer cells preclude any firm conclusion on the potential of Mabs use in the treatment of ovarian cancer. Oregovomab, directed against CA 125, and bevacizumab, targeting VEGF, are two unconjugated Mabs closest to
\end{abstract}

Correspondence to: Dr Angèle L.M. Oei, Radboud University Nijmegen Medical Centre, Department of Obstetrics and Gynecology, P.O. box 9101, 6500 HB Nijmegen, The Netherlands

E-mail: a.oei@obgyn.umcn.nl

Abbreviations: ADCC, antibody dependent cell mediated cytotoxicity; Ab1, anti-idiotypic antibody directed against the tumor associated antigen; Ab2, anti-idiotypic antibody directed against $\mathrm{Ab} 1 ; \mathrm{Ab} 3$, anti-idiotypic antibody directed towards the tumorassociated antigen and $\mathrm{Ab} 2$; CCR, complete clinical remission; CDC, complement derived cytotoxicity; CT, computed tomography; HAMA, human anti-mouse antibodies; Mabs, monoclonal antibodies; PFS, progression-free survival; RIS, radioimmunoscintigraphy; RIT, radioimmunotherapy; TTR, time to relapse

Key words: ovarian cancer, monoclonal antibodies, CA 125, gp38, HER2, HMFG, MUC1, TAG 72, VEGF clinical introduction for the treatment of ovarian cancer. Vaccination with Mab ACA 125 seems promising but these findings need to be confirmed in controlled randomized trials. Sole RIT should be investigated with the appropriate radionuclide and a Mab with high affinity for the specific tumor-associated antigen in the appropriate patient group to determine whether it may have a therapeutic effect. Additionally, appending (radio)immunotherapy with antiTAG 72 or anti-MUC1 to other treatment strategies such as chemotherapy could also be a strategy worthwhile investigating. The potential of Mabs to complement current treatment paradigms, is encouraging and may bring a significant improvement to the overall therapeutic outcomes currently being achieved in ovarian cancer.

\section{Contents}

1. Introduction

2. Background

3. Antibody features

4. Antibody-based therapy

5. Immunogenicity

6. Toxicity

7. Clinical trials

8. Conclusions

\section{Introduction}

Ovarian cancer is the fourth leading cause of cancer-related death in women, and accounts for the highest mortality rate of all gynecological malignancies (1). Its poor prognosis is mainly the result of the clinically occult nature of this disease. The peritoneal cavity in which the ovaries are localized provides a perfect environment for undisturbed subclinical growth. Furthermore, early detection is difficult because of the general asymptomatic presentation of the disease (2). In the majority (68\%) of the patients, ovarian cancer is diagnosed with at least extensive abdominal spread (3). Standard treatment for advanced stage ovarian cancer is tumor debulking surgery and adjuvant chemotherapy. Although most ovarian cancers are sensitive to platinumbased chemotherapy, the prognosis remains poor. The 5-year 
survival of patients with advanced disease, FIGO stage IIIc and IV is respectively 29 and $13 \%(2,4)$.

There is a need for new treatment modalities. Antibodybased therapy such as immunotherapy with unconjugated antibodies, vaccination and (radio)immunotherapy (RIT) could be treatment modalities useful for this disease. In most patients ovarian cancer growth is confined to the peritoneal cavity. One of the advantages of (radio)immunotherapy is the possibility of regional administration, thereby limiting systemic side-effects. Besides this, a series of ovarian cancerassociated antigens have been identified during the past few decades which may serve as potential targets for antibodybased (radio)immunotherapy. These developments, which use monoclonal antibodies (Mabs) as 'magic bullets' are attractive alternative options for the treatment of ovarian cancer.

In recent clinical studies in non-Hodgkin lymphoma patients, antibody-based therapy has shown remarkable response rates and, for this reason became a standard element in the treatment of these malignancies $(5,6)$. Similar results were obtained with antibody-based therapies in several solid malignancies (7-9). The aim of the present review is to provide background information on Mab-based therapy in general and to give an overview of published clinical trials with unconjugated Mabs, vaccination and/or RIT with Mabs for the treatment of ovarian cancer.

\section{Background}

The therapeutic appeal of antibodies can be traced back more than a century ago, when mice were first investigated as a possible source of antibodies. Scientists injected mice with infectious agents in order to stimulate the production of antibodies against the micro-organisms. It was hypothesized that patients suffering from the same type of infection could be treated with an injection of infected rodents' serum. However, these crude preparations were ineffective, and the sera sparked adverse immune reactions in some patients (10).

The idea to use antibodies as 'magic bullet' was first postulated by Paul Ehrlich at the end of the 19th century (11). Ehrlich proposed the concept that immune cells secrete 'Seitenketten', which we now know as antibodies, in response to foreign antigens. He postulated that these antibodies could be used to specifically attack a wide variety of pathogens, using them as 'magic bullets' to target the site of disease. In 1975 Köhler and Milstein discovered a method for producing monoclonal antibodies by in vitro fusion of immune spleen cells and immortal murine myeloma cells (12). This discovery has allowed for the production of large amounts of identical and specific antibodies for the diagnosis and treatment of cancer, as well as several other diseases. More recently, genetic engineering has enabled the development of chimeric and humanized antibodies, in order to reduce the immunogenicity of the antibodies. Antibodies and IgG fragments were further linked with toxins, radionuclides, enzymes, chemotherapeutic agents and cytokines for diagnostic and therapeutic purposes (13). Subsequently, various Mabs against ovarian cancer-associated antigens have been developed to try to improve diagnosis and therapy.

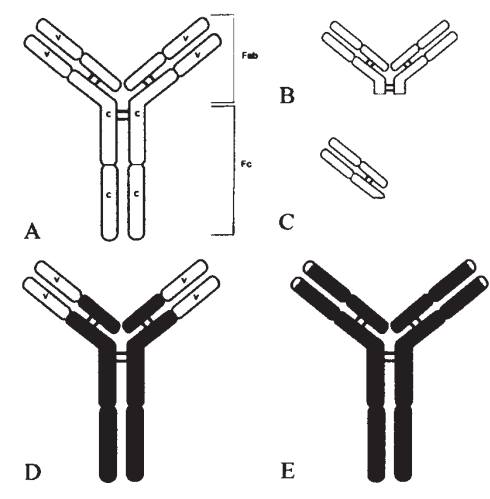

Figure 1. Monoclonal antibody structures mainly used in (radio)immunotherapy. (A) Whole (murine) IgG. V variable regions, C constant regions. (B) $\mathrm{F}\left(\mathrm{ab}^{\prime}\right)_{2}$ fragment. (C) $\mathrm{F}(\mathrm{ab}$ ') fragment. (D) Chimeric IgG, the constant regions of the murine Mab have been replaced by their human analogues (black). (E) Humanized IgG (90-95\% human).

\section{Antibody features}

Antibodies or immunoglobulins are a group of glycoproteins present in serum and tissue of all mammals. They are produced by B-lymphocytes in response to a pathogenic challenge and trigger the immune system to react against this pathogen. The immunoglobulin is composed of two identical light chains and two identical heavy chains linked together by disulphide bonds. An immunoglobulin G (IgG) molecule consists of two Fab domains, containing antigen-binding site, and one Fc domain, which is responsible for activation of the immune system (Fig. 1).

There are five distinct classes of immunoglobulins, IgG, $\operatorname{Ig} \mathrm{A}, \operatorname{IgM}, \operatorname{IgD}, \operatorname{IgE}$, of which $\operatorname{IgG}$ is most commonly used in diagnostic and therapeutic applications. IgG antibodies have a molecular weight of $150 \mathrm{kDa}$ and are characterized by a slow clearance from the blood resulting in long circulatory half-life ( $>3$ days). When targeting a tumor these antibodies show a heterogeneous intra-tumoral distribution (14).

Smaller antibody fragments have been produced in order to achieve more rapid blood clearance. Proteolytic degradation of IgG with pepsin results in antibody fragments; $\mathrm{F}\left(\mathrm{ab} \mathrm{b}^{\prime}\right)_{2}$ (MW 100 kDa) and Fab' (MW 50 kDa), respectively (Fig. 1). Tumor uptake of these fragments is faster and more homogeneous than whole IgG molecules, but the absolute tumor uptake is lower and retention time is shorter as compared to that of intact Mab (15). Furthermore, an important difference between intact Mabs and Mab fragments is their route of clearance from the body. Intact Mabs are catabolized in the liver and spleen, whereas Mab fragments are mainly excreted via the kidneys (16). Consequently, the application of radiolabeled Mab fragments for therapy will result in an increased renal radiation dose.

\section{Antibody-based therapy}

The anti-tumor effects induced by injecting Mabs are generated by different mechanisms. Upon binding of the Fc receptor of the injected Mabs to the effector cells, the Fc region triggers an antibody-dependent cell-mediated cytotoxicity (ADCC) response resulting in lysis of the target cells 


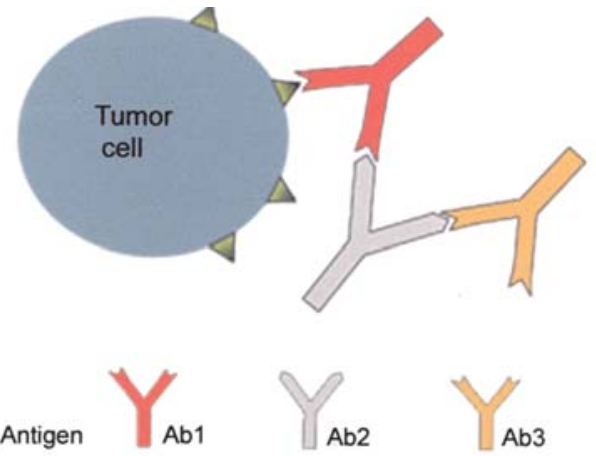

Figure 2. The variable region of the murine monoclonal antibody binds with the antigen. The variable region of the murine monoclonal antibody (Ab1) contains unique structures, which stimulate the production of various antiantibodies (Ab2). Some Ab2 express the variable-region structures (internal image) which mimic the antigen (MUC1) and therefore can stimulate the production of antibodies similar to the monoclonal antibody (Ab3). Ab3 may be similar to Ab1 and thus may react with MUC1. Each antibody generation induces the production of still another and larger set of antiantibodies in a similar cascade-like manner.

(17). Furthermore, activation of the complement system could thus, induce complement dependent cytotoxicity (CDC) of tumor cells. Some Mabs induce apoptosis while other Mabs may block growth factor receptors on cancer cells and/or may sensitize cancer cells for example for chemotherapy and radiotherapy (17). Moreover, Mabs may act as anti-angiogenic agents, such as bevacizumab that blocks vascular endothelial growth factors (VEGF) and thus inhibits angiogenesis (17). Furthermore, a humoral immune response may be induced if the injected Mab is recognized as a foreign protein. This humoral response can either be an anti-isotypic and/or an anti-idiotypic response. Anti-isotypic antibodies are directed towards antigenic determinants on the constant regions of the murine immunoglobulin molecule. Anti-idiotypic antibody response (Ab2) is directed against the hypervariable regions of the injected Mab. The presence of antiidiotypic antibodies theoretically can evoke a second immune response by producing anti-anti-idiotypic antibodies (Ab3). The antigen binding region of these $\mathrm{Ab} 3$ antibodies is directed towards the antigen binding region of $\mathrm{Ab} 2$ and resembles the antibody (Ab1) that elicited the original anti-idiotypic antibody response (18). This cascade-like manner, in which each antibody generation induces the production of another set of antibodies was first described by Jerne and is called 'The Jerne network theory' (Fig. 2) (19).

Assuming that the idiotypic network of Jerne does exist, vaccination with $\mathrm{Ab} 1$ or $\mathrm{Ab} 2$ may be an attractive treatment strategy. Immunization with Ab1, specifically directed towards the tumor-associated antigen, or Ab2, resembling the antigen, may result in the production of $\mathrm{Ab} 3$, which recognizes the corresponding original antigen. If so, complex formation between the antigen present on the tumor cell surface and the induced Ab3 may induce ADCC, CDC and/ or apoptosis of tumor cells.

The use of Mabs in RIT is based on the idea of specifically targeting the tumor cells that express the tumorassociated antigens. Hereby, the radiation dose is delivered locally, optimizing the dose at the tumor site and minimizing radiation damage to the healthy tissues.
The three Mab-based treatment strategies with Mab, i.e. unconjugated Mabs therapy, vaccination with Mabs and RIT will be discussed below.

\section{Immunogenicity}

The activation of the immune system by Mabs may be beneficial for the recipient but also have negative effects. Injected murine Mabs may evoke a humoral immune response in which human anti-mouse antibodies (HAMA) are produced (20). About $50-75 \%$ of patients with solid tumors develop HAMA after exposure to mouse Mabs, depending on the Mab and the antibody form (IgG or fragments) (21). Complex formation between the injected antibody and HAMA may result in a faster clearance of the antibody, increased hepatic and splenic uptake and reduced tumor uptake when Mabs are repeatedly administered (22). The magnitude and duration of the HAMA response in serum shows great variability and is more likely to occur after repeated injection of Mabs $(20,23)$. HAMA can persist in blood for several months after exposure to mouse immunoglobulin. B-memory cells that produce these specific antibodies presumably remain present for years and will be re-activated upon re-exposure to the antigenic stimulus $(21,24)$.

Hence, the development of HAMA has been considered a disadvantage in the treatment with Mabs (21). Interestingly, HAMA development has also been associated with a positive outcome on survival, by inducing the production of antianti-idiotypic antibodies (Ab3) (25-28). Induction of Ab3 following injection of Mabs to tumor-associated antigens (TAA), has been associated with cancer regression in animal models and cancer patients $(26,28)$. To avoid the negative side-effects of HAMA development after treatment with Mabs, chimeric and humanized antibodies have been developed. Chimeric antibodies are Mabs in which the constant domains of the human $\mathrm{IgG}$ molecule are combined with the murine variable regions by transgenic fusion of the immunoglobulin genes (Fig. 1) (29). The application of chimeric antibodies indeed reduced HAMA responses substantially, but did not eliminate them completely in most cases. Next, humanized antibodies were developed in which the 6 complementarity determining regions (CDRs) of the heavy and light chains and a limited number of structural amino acids of the murine Mab were grafted, by recombinant technology, to the CDRdepleted human IgG scaffold (Fig. 1) $(30,31)$.

\section{Toxicity}

Despite earlier concerns, adverse events as a result of the development of HAMA during and after immunotherapy or radioimmunotherapy have not proven to be significant (21). Remarkably few anaphylactic reactions have been reported, suggesting that they are quite uncommon $(20,21)$. However, adverse reactions after Mab therapy due to a developed HAMA may occur, and the following reactions have been reported: allergic reactions, anaphylactic shock, generalized pain, hyponatremia, fever, rigors and chills, rash, paresthesias, weakness, chronic refractory postural hypotension, serum sickness, cytokine release syndrome and tumor lysis syndrome (32-35). When adverse events do occur they generally occur 
Table I. Clinical trials in ovarian cancer with Mab directed towards antigen CA 125.

\begin{tabular}{|c|c|c|c|c|c|}
\hline Authors (Refs.) & MAb & No. of patients & Dosage & Response & Special features \\
\hline Method et al (52) & B43.13 & 102 consolidation & $2 \mathrm{mg}$, repeated, iv & - & $\begin{array}{l}\text { Immune response correlated with } \\
\text { improved clinical outcomes }\end{array}$ \\
\hline Ehlen et al (46) & B43.13 & 13 recurrent & $2 \mathrm{mg}$, repeated, iv & $3 \mathrm{SD}, 10 \mathrm{PD}$ & $\begin{array}{l}\text { SD in patients with robust } \\
\text { immune response }\end{array}$ \\
\hline Berek et al (37) & B43.13 & $145 \mathrm{CCR}$ & $2 \mathrm{mg}$, repeated, iv & - & No difference in time to relapse \\
\hline Gordon et al (48) & B43.13 & 20 recurrent & $2 \mathrm{mg}$, repeated, iv & $\begin{array}{l}2 \mathrm{CR}, 1 \mathrm{PR} \\
3 \mathrm{SD}, 9 \mathrm{PD}\end{array}$ & $\begin{array}{l}\text { Improved survival in patients } \\
\text { with T-cell response to CA } 125\end{array}$ \\
\hline Ehlen et al (45) & B43.13 & 345 consolidation & $2 \mathrm{mg}$, repeated, iv & - & $\begin{array}{l}\text { Specific immune response longer } \\
\text { median time to progression }\end{array}$ \\
\hline Pfisterer et al (62) & ACA 125 & 36 recurrent & $2 \mathrm{mg}$, repeated, sc & $11 \mathrm{PD}$ & Premature termination \\
\hline Schultes et al (54) & B43.13 & 75 & $2 \mathrm{mg}$, repeated, iv & - & $\mathrm{Ab} 2$ responders longer survival \\
\hline Reinartz et al (59) & ACA 125 & 119 & $2 \mathrm{mg}$, repeated, im & - & $\begin{array}{l}\text { Specific immune response } \\
\text { resulted in longer survival }\end{array}$ \\
\hline Wagner et al (61) & ACA 125 & 42 reccurent & $2 \mathrm{mg}$, repeated, im & - & $\begin{array}{l}\text { Specific immune response } \\
\text { resulted in longer survival }\end{array}$ \\
\hline Wagner et al (60) & ACA 125 & $\begin{array}{l}16 \text { advanced } \\
\text { and recurrent }\end{array}$ & $2 \mathrm{mg}$, repeated, iv & - & $\begin{array}{l}\text { CA } 125 \text {-specific immune } \\
\text { responders showed longer PFS }\end{array}$ \\
\hline Mobus et al (72) & ${ }^{99} \mathrm{Tc}-\mathrm{B} 43.13$ & 44 recurrent & $2 \mathrm{mg}$, repeated, iv & $6 \mathrm{CR}$ & $\begin{array}{l}\text { HAMA responders longer } \\
\text { survival }\end{array}$ \\
\hline Mahe et al (69) & ${ }^{131} \mathrm{I}-\mathrm{OC} 125$ & 6 residual & $60 \mathrm{mg}$, ip & $2 \mathrm{SD}, 4 \mathrm{PD}$ & - \\
\hline Baum et al (65) & $\begin{array}{l}{ }^{111} \mathrm{In}-\mathrm{OC} 125, \\
{ }^{99} \mathrm{Tc}-\mathrm{B} 43.13\end{array}$ & 32 & Repeated, iv & $\begin{array}{l}7 \mathrm{CCR}, \\
\text { or SD }\end{array}$ & $\begin{array}{l}\text { Anti-idiotypic HAMA } \\
\text { responders longer survival }\end{array}$ \\
\hline Muto et al (73) & ${ }^{131} \mathrm{I}-\mathrm{OC} 125$ & 29 refractory & $10-65 \mathrm{mg}$, ip & $1 \mathrm{CR}, 28 \mathrm{PD}$ & - \\
\hline
\end{tabular}

after the first Mab administration (21,34). The studies reported to date indicate that depending on the Mab, the majority of the Mab-based therapies can be safely applied with minimal adverse effects (21).

\section{Clinical trials}

A search for antibody-based trials for the treatment of ovarian cancer was performed in the Pubmed and Medline databases until October 1, 2007. The following keywords were used for the search: monoclonal antibodies, ovarian cancer, CA 125, HER2, gp38, HMFG, MUC1, TAG 72 and VEGF. The search was limited by only including clinical trials in humans and written in the English language.

A total of 44 Mab based trials in ovarian cancer patients have been published, 42 of which are phase I/II and two phase III trials dealing with patients receiving Mab. Mabs were administered using the intravenous (iv), intramuscular (im), intradermal, intraperitoneal (ip) and subcutaneous (sc) route. To date, 15 different antibodies have been used directed against 5 different tumor-associated antigens and one antiangiogenesis antigen (VEGF). Of the 44 clinical trials, 23 trials studied immunotherapy with unconjugated Mab (27,36-57), five trials studied vaccination with Mabs (58-62), while 16 trials studied RIT (63-78). Two of the RIT trials used a combination of cytotoxic chemotherapy and RIT $(64,71)$. A combination of unconjugated Mabs combined with cytotoxic chemotherapy administration was assessed in four trials $(43,47,53,57)$. Because of the high propensity to stay confined to the peritoneal cavity until very late in the course of the disease, many trials on radiolabeled Mab in ovarian cancer patients used the ip route for administration $(19 / 44)(38,41,44,50,51,63,64,66-71,73-78)$. In 20 studies the Mab was administered iv $(36,37,39,40,42,43,45-49,52-$ $55,57,60,65,72,79)$, two studies injected im $(59,61)$, while 2 other studies used both iv and ip routes of administration 
Table II. Clinical trials in ovarian cancer with Mab directed towards antigen Folate receptor (gp38).

\begin{tabular}{|c|c|c|c|c|c|}
\hline Authors (Refs.) & MAb & No. of patients & Dosage & Response & Special features \\
\hline $\begin{array}{l}\text { Zanten-Przybysz } \\
\text { et al (56) }\end{array}$ & cMOv18 & 5 & $50 \mathrm{mg}$ repeated, iv & $2 \mathrm{SD}, 3 \mathrm{PD}$ & $\begin{array}{l}\text { Patients with recurrent or } \\
\text { residual disease }\end{array}$ \\
\hline $\begin{array}{l}\text { Crippa et al } \\
(66)\end{array}$ & ${ }^{131} \mathrm{I}-\mathrm{Mov} 18$ & 16 & $14 \mathrm{mg}$, ip & $\begin{array}{l}5 \mathrm{CR}, 6 \mathrm{SD} \\
5 \mathrm{PD}\end{array}$ & $\begin{array}{l}\text { Third-look laparoscopy for } \\
\text { tumor response }\end{array}$ \\
\hline $\begin{array}{l}\text { Miotti et al } \\
(27)\end{array}$ & $\mathrm{OC} / \mathrm{TR}$ & 35 & $\begin{array}{l}\text { Different schedules, } \\
\text { ip and iv }\end{array}$ & - & $\begin{array}{l}\text { High HAMA levels associated } \\
\text { with improved clinical response }\end{array}$ \\
\hline $\begin{array}{l}\text { Lamers et al } \\
(51)\end{array}$ & $\mathrm{OC} / \mathrm{TR}$ & 13 residual & $\begin{array}{l}\text { Different schedules, } \\
\text { ip }\end{array}$ & $\begin{array}{l}4 \mathrm{PR}, 1 \mathrm{SD} \\
1 \mathrm{CR}\end{array}$ & $\begin{array}{l}\text { OC/TR re-targeted with } \\
\text { T-lymphocytes and IL-2 }\end{array}$ \\
\hline $\begin{array}{l}\text { Lamers et al } \\
(50)\end{array}$ & OC/TR & 8 & $\begin{array}{l}\text { Different schedules, } \\
\text { ip }\end{array}$ & - & $\begin{array}{l}\text { OC/TR re-targeted with } \\
\text { T-lymphocytes and IL-2 }\end{array}$ \\
\hline $\begin{array}{l}\text { Canevari et al } \\
(41)\end{array}$ & OC/TR & 28 & Repeated, ip & $\begin{array}{c}3 \mathrm{CR}, 3 \mathrm{PR} \\
7 \mathrm{SD}\end{array}$ & $\begin{array}{l}\text { OC/TR re-targeted with } \\
\text { T-lymphocytes }\end{array}$ \\
\hline $\begin{array}{l}\text { Bolhuis et al } \\
(38)\end{array}$ & OC/TR & 13 & Repeated, ip & $\begin{array}{l}5 \mathrm{CR}, 3 \mathrm{PR}, \\
2 \mathrm{SD}, 3 \mathrm{PD}\end{array}$ & $\begin{array}{l}\text { OC/TR re-targeted with } \\
\text { T-lymphocytes }\end{array}$ \\
\hline
\end{tabular}

See also legend of Fig. 1.

$(27,58)$, one study administered through ip, iv and intradermal routes (58) and one study only used sc route of Mabs administration (62). The median number of patients included was 29 (range 3-447). Fourteen trials included patients with ovarian cancer stages Ic through IV. The majority of trials (22/44) included patients with residual, refractory or recurrent ovarian cancer. Five trials included patients in complete clinical remission and three trials included patients after debulking and/or chemotherapy. Mab therapy targeting the CA 125 antigen was used in 14 trials of which four RIT trials and three vaccination trials (Table I). Anti-folate receptor Mabs (gp38) were used in seven trials of which one evaluated RIT (Table II). Anti-HER2 Mabs were used in five trials (Table III). Seven trials evaluated anti-MUC1 Mabs of which 6 were RIT trials, and one a vaccination trial (Table IV). AntiTAG 72 Mabs were used in 6 RIT trials (Table V). AntiVEGF Mabs were used in 5 immunotherapy trials (Table VI). The following sections discuss these trials according to the antigen that was targeted.

Cancer antigen (CA) 125. The tumor associated-cancer antigen CA 125 is detectable on tumor cells in over $90 \%$ of the patients with advanced epithelial ovarian cancer (80). An overview of Mab trials directed towards CA 125 is shown in Table I. OC125 was the first antibody directed to CA 125 and was used in radioimmuno-scintigraphy (RIS) trials administering OC125 labeled with a diagnostic dose of 131Iodium in ovarian cancer patients (73). A RIS study by Muto et al (73) also used ${ }^{131}$ I-labeled OC125 for RIS in patients with recurrent ovarian cancer. Interestingly, it was found that patients who developed HAMA and/or Ab2 had a prolonged median survival. Another phase II study in ovarian cancer patients treated with ip ${ }^{131} \mathrm{I}-\mathrm{OC} 125-\mathrm{F}\left(\mathrm{ab}^{\prime}\right)_{2},(120 \mathrm{mCi})$ for consolidation did not show a beneficial therapeutic effect (69).

MAb-B43.13 also known as oregovomab and OvaRex ${ }^{\circledR}$ is a more recently develop murine Mab also directed to CA 125. One of the first RIS studies with ${ }^{99 \mathrm{~m} T c-B 43.13}$ showed an unexpected prolonged survival in 26 ovarian cancer patients receiving RIS compared to a control group $(69,80)$. The improved clinical outcome was suggested to be due to the induction of the idiotypic cascade by this Mab (Ab1) (65). Further investigation of the immune response showed activation of both a humoral and a cellular CA 125 specific responses. A double-blind, placebo-controlled trial in which 145 epithelial ovarian cancer patients were treated with repeated iv B43.13 injections as consolidation therapy confirmed the induction of HAMA and Ab2 (37). However, the study did not demonstrate a prolonged time to relapse (TTR). Comparing the group of patients who developed human anti-B43.13 antibodies (Ab2 responder group) to the Ab2 non-responder group, there was a difference in TTR of respectively, 18.8 months and 6.1 months (cut-off Ab2 response at $100 \mathrm{ng} / \mathrm{ml}$ ). The induction of an immunological response monitored as HAMA and Ab2 response was also associated with a significant advantage in disease-free survival in other studies using B43.13. (45,46,52,54,72). Gordon et al (48) studied the combination of chemotherapy and immunotherapy with oregovomab in patients with recurrent epithelial ovarian cancer. They found that oregovomab in combination with standard chemotherapy was well-tolerated and induced multiple antigen-specific immune responses, which had a significant survival benefit in immune responders of the 20 
Table III. Clinical trials in ovarian cancer with Mab directed towards antigen HER2.

\begin{tabular}{|c|c|c|c|c|c|}
\hline Authors (Refs.) & MAb & No. of patients & Dosage & Response & Special features \\
\hline $\begin{array}{l}\text { Seiden et al } \\
(55)\end{array}$ & EMD7200 & 37 recurrent & $\begin{array}{l}800 \mathrm{mg}, \\
\text { weekly, iv }\end{array}$ & - & $\begin{array}{l}\text { Well tolerated, no clinical effect } \\
\text { of matuzumab }\end{array}$ \\
\hline $\begin{array}{l}\text { Gordon et al } \\
\text { (49) }\end{array}$ & $\mathrm{Hu} 2 \mathrm{C} 4$ & 123 recurrent & Two schedules, iv & $\begin{array}{l}5 \mathrm{PR}, 8 \mathrm{SD}, \\
10 \mathrm{CA} 125, \\
\text { reduction }\end{array}$ & Response rate of $4.3 \%$ \\
\hline $\begin{array}{l}\text { Agus et al } \\
(36)\end{array}$ & $\mathrm{Hu} 2 \mathrm{C} 4$ & 3 & $5 \mathrm{mg} / \mathrm{kg}$, iv & $1 \mathrm{SD}, 1 \mathrm{PR}, 1 \mathrm{PD}$ & - \\
\hline $\begin{array}{l}\text { Bookman et al } \\
\text { (39) }\end{array}$ & $\mathrm{Hu}$ 4D5 & 41 & $4 \mathrm{mg} / \mathrm{kg}$, iv & $1 \mathrm{CR}, 1 \mathrm{PR}$ & $\begin{array}{l}\text { Start with } 4 \mathrm{mg} \text { followed with } \\
2 \mathrm{mg} / \mathrm{kg} \text { weekly }\end{array}$ \\
\hline $\begin{array}{l}\text { De Gramont et al } \\
\text { (44) }\end{array}$ & MDX-H210 & 14 & Repeated,iv & $6 \mathrm{CR}, 5 \mathrm{PD}, 3 \mathrm{SD}$ & $\begin{array}{l}\text { Combined monocyte-derived } \\
\text { activated killer (MAK) cells with } \\
\text { the bispecific Mab MDX- } 210\end{array}$ \\
\hline
\end{tabular}

See also legend of Fig. 1.

Table IV. Clinical trials in ovarian cancer with Mab directed towards antigen MUC1.

\begin{tabular}{|c|c|c|c|c|c|}
\hline Authors (Refs.) & MAb & No. of patients & Dosage & Response & Special features \\
\hline $\begin{array}{l}\text { Nicholson et al } \\
\text { (58) }\end{array}$ & HMFG1 & $\begin{array}{l}6 \text { residual or } \\
\text { relapse or CCR }\end{array}$ & $\begin{array}{l}\text { Different schedules } \\
\text { Ip. and iv }\end{array}$ & $3 \mathrm{PD}$ & $\begin{array}{l}\text { iv. or ip. priming followed by } 6 \\
\text { intradermal vaccination }\end{array}$ \\
\hline $\begin{array}{l}\text { Verheijen et al } \\
\text { (78) }\end{array}$ & ${ }^{90} \mathrm{Y}-\mathrm{HMFG} 1$ & $447 \mathrm{CCR}$ & $25 \mathrm{mg}$, ip & 202 PD & No survival benefit \\
\hline $\begin{array}{l}\text { Nicholson et al } \\
\text { (75) }\end{array}$ & ${ }^{90} \mathrm{Y}-\mathrm{HMFG} 1$ & $107 \mathrm{CCR}$ & $25 \mathrm{mg}$, ip & - & No survival benefit \\
\hline $\begin{array}{l}\text { Epenetos et al } \\
(67)\end{array}$ & ${ }^{90} \mathrm{Y}-\mathrm{HMFG} 1$ & $\begin{array}{c}21 \mathrm{CCR}, \\
31 \text { residual } \\
\text { disease }\end{array}$ & $25 \mathrm{mg}$, ip & - & Survival: $78 \%$ at 10 -year follow-up \\
\hline $\begin{array}{l}\text { Nicholson et al } \\
\text { (74) }\end{array}$ & ${ }^{90} \mathrm{Y}-\mathrm{HMFG} 1$ & $\begin{array}{c}25 \text { after } \\
\text { debulking }\end{array}$ & $25 \mathrm{mg}$, ip & - & $\begin{array}{l}10 \text {-year survival patients } 70 \% \text {, control } \\
32 \%\end{array}$ \\
\hline $\begin{array}{l}\text { Hird et al } \\
(68)\end{array}$ & ${ }^{90} \mathrm{Y}-\mathrm{HMFG} 1$ & 52 & $25 \mathrm{mg}$, ip & - & $\begin{array}{l}\text { Patients have longer survival compared } \\
\text { to historical controls }\end{array}$ \\
\hline $\begin{array}{l}\text { Stewart et al } \\
(77)\end{array}$ & $\begin{array}{l}{ }^{90} \text { Y-HMFG1, } \\
+ \text { AUA1 }\end{array}$ & 25 & $18 \mathrm{mg}$, ip & $1 \mathrm{PD}, 1 \mathrm{SD}$ & $\begin{array}{l}\text { AUA1 to } 35 \mathrm{kd} \text { cell surface antigen } \\
\text { expressed in } 75 \% \text { ovca }\end{array}$ \\
\hline
\end{tabular}

See also legend of Fig. 1.

patients participating in the trial. The administration of murine B43.13 to patients led to the induction of HAMA, CA 125 specific antibodies, $\mathrm{T}$ helper cells, and cytotoxic $\mathrm{T}$ cells, generating both a cellular and humoral response to the tumor antigen (54,81).

ACA 125 is a murine anti-idiotypic antibody (Ab2) that mimics the epitope of the CA 125 antigen. Theoretically vaccination of patients with this Mab could induce the generation of Ab3. ACA 125 has shown to induce a humoral as well as a cellular anti-CA 125-specific immune response in animals and humans $(60,61,82)$. In a phase I/II trial conducted by Wagner et al (61) 42 patients with recurrent ovarian cancer received 4 im immunizations with anti-idiotypic Mab ACA 125. In this trial Ab3 was detected in $67 \%$ of the patients. 
Table V. Clinical trials in ovarian cancer with Mab directed towards antigen TAG 72.

\begin{tabular}{|c|c|c|c|c|c|}
\hline Authors (Refs.) & $\mathrm{MAb}$ & No. of patients & Dosage & Response & Special features \\
\hline $\begin{array}{l}\text { Alvarez et al } \\
(64)\end{array}$ & ${ }^{90} \mathrm{Y}-\mathrm{CC} 49$ & $\begin{array}{l}20 \text { recurrent } \\
\text { or persistent }\end{array}$ & $5 \mathrm{mg}$, ip & $\begin{array}{l}5 \mathrm{SD}, 2 \mathrm{PR} \\
4 \mathrm{ND}\end{array}$ & $\begin{array}{l}\text { Combination with subcutanous IFN and IP } \\
\text { paclitaxel }\end{array}$ \\
\hline $\begin{array}{l}\text { Meredith et al } \\
\text { (71) }\end{array}$ & ${ }^{177} \mathrm{Lu}-\mathrm{CC} 49$ & $\begin{array}{l}44 \text { recurrent } \\
\text { or persistent }\end{array}$ & Repeated, ip & $4 \mathrm{SD}, 4 \mathrm{PR}$ & $\begin{array}{l}\text { Combination with IFN subcutaneous and } \\
\text { IP Taxol }\end{array}$ \\
\hline $\begin{array}{l}\text { Alvarez et al } \\
(63)\end{array}$ & ${ }^{177} \mathrm{Lu}-\mathrm{CC} 49$ & 27 refractory & $20 \mathrm{mg}$, ip & $7 \mathrm{SD}, 2 \mathrm{PR}$ & - \\
\hline $\begin{array}{l}\text { Meredith et al } \\
\text { (70) }\end{array}$ & ${ }^{177} \mathrm{Lu}-\mathrm{CC} 49$ & 12 refractory & $20 \mathrm{mg}$, ip & $\begin{array}{l}1 \mathrm{PR}, 3 \mathrm{CR} \\
5 \mathrm{PD}, 1 \mathrm{SD}\end{array}$ & - \\
\hline $\begin{array}{l}\text { Rosenblum et al } \\
\text { (76) }\end{array}$ & ${ }^{90} \mathrm{Y}-\mathrm{B} 72.3$ & $\begin{array}{l}58 \text { recurrent } \\
\text { or refractory }\end{array}$ & $2-10 \mathrm{mg}$, ip & $\begin{array}{l}2 \mathrm{CR}, 2 \mathrm{PR} \\
30 \mathrm{SD}\end{array}$ & - \\
\hline
\end{tabular}

See also legend of Fig. 1.

Table VI. Clinical trials in ovarian cancer with Mab directed towards antigen VEGF.

\begin{tabular}{|c|c|c|c|c|c|}
\hline Reference & MAb & No. of patients & Dosage & Response & Special features \\
\hline $\begin{array}{l}\text { Wright et al } \\
(57)\end{array}$ & bevacuzimab & 23 recurrent & $5 \mathrm{mg} / \mathrm{kg}$, iv & $\begin{array}{l}8 \mathrm{PR}, 10 \mathrm{SD}, \\
5 \mathrm{PD}\end{array}$ & $\begin{array}{l}\text { In combination with cytotoxic chemo- } \\
\text { therapy }\end{array}$ \\
\hline $\begin{array}{l}\text { Cohn et al } \\
\text { (43) }\end{array}$ & bevacuzimab & 10 refractory & $10 \mathrm{mg} / \mathrm{kg}$, iv & $5 \mathrm{PD}, 4 \mathrm{PR}$ & $\begin{array}{l}\text { In combination with cytotoxic chemo- } \\
\text { therapy }\end{array}$ \\
\hline $\begin{array}{l}\text { Monk et al } \\
(53)\end{array}$ & bevacuzimab & 32 refractory & $15 \mathrm{mg} / \mathrm{kg}$, iv & $8 \mathrm{PR}, 5 \mathrm{PD}$ & $\begin{array}{l}\text { Partial in combination with cytotoxic } \\
\text { chemotherapy }\end{array}$ \\
\hline $\begin{array}{l}\text { Cannistra et al } \\
\text { (42) }\end{array}$ & bevacuzimab & 44 refractory & $15 \mathrm{mg} / \mathrm{kg}$, iv & $\begin{array}{l}10 \mathrm{PFS}, 7 \mathrm{PR}, \\
20 \mathrm{SD}\end{array}$ & $27.4 \%$ PFS of 6 months \\
\hline $\begin{array}{l}\text { Garcia et al } \\
(47)\end{array}$ & bevacuzimab & 29 recurrent & $10 \mathrm{mg} / \mathrm{kg}$, iv & $\begin{array}{l}6 \mathrm{PR}, 17 \mathrm{SD}, \\
6 \mathrm{PD}\end{array}$ & $\begin{array}{l}\text { In combination with cytotoxic } \\
\text { chemotherapy } 47 \% \text { PFS of } 6 \text { months }\end{array}$ \\
\hline $\begin{array}{l}\text { Burger et al } \\
(40)\end{array}$ & bevacuzimab & 62 recurrent & $15 \mathrm{mg} / \mathrm{kg}$, iv & $\begin{array}{l}3 \mathrm{CR}, 8 \mathrm{PR} \\
34 \mathrm{SD}, 17 \mathrm{PD}\end{array}$ & $38.7 \%$ had stable disease for $>6$ months \\
\hline
\end{tabular}

See also legend of Fig. 1.

The mean survival of patients with an Ab3 response was $19.9 \pm 13.3$ months, compared to only $5.3 \pm 4.3$ months for those without an immune response. These results suggest that vaccination with the ACA 125 antibody could have a significant impact on clinical outcome. A continuation of this research by Reinartz et al (59) included 119 advanced ovarian cancer patients who received an average of 9.7 ACA $125 \mathrm{im}$ injections. In $68 \%$ of the patients an Ab3 reaction occurred, which was associated with a significantly longer survival (23.4 months) as compared to patients who were Ab3 negative (4.9 months). CA 125 specific antibodies (Ab3) and ADCC of CA 125 positive tumor cells in vitro was observed in 50.4 and $26.9 \%$ of the patients, respectively. Although this study had an uncontrolled set-up, the data strongly support a relationship between the development of Ab3 and overall survival time of ovarian cancer patients with disease recurrence. A causal relation between Ab3 and disease outcome has not yet been confirmed. Recently, Pfisterer et al (62) performed a phase I trial in 36 recurrent ovarian cancer patients on the effect of subcutaneous administration of ACA 125 which was prematurely terminated due to patient withdrawal or disease progression. However, sc administration of ACA 125 did seem safe and was well-tolerated also in highly frequent dosage schedules (62).

The results of the studies cited above indicate the need for further investigation on the efficacy of antibody-based therapy directed against the CA 125 antigen in randomized clinical trials. Immunotherapy with oregovomab seems to be 
an attractive alternative as consolidation therapy in ovarian cancer patients.

Folate receptor. The Mab MOv18 binds to the membrane folate receptor (gp38) which is overexpressed in $\sim 90 \%$ of epithelial ovarian cancers (83). MOv18 is directed to the $\alpha$ isoform of the folate receptor. Van Zanten-Przybysz et al (56) treated 5 patients with recurrent or residual disease with four iv injections of $50 \mathrm{mg}$ chimeric MOv18 (cMOv18). This strategy had minor side-effects but showed little if any effect on survival (56). In several phase I/II studies the administration of radiolabeled cMOv18 by iv and ip routes proved to be able to deliver therapeutic radiation doses to the tumor with minor side-effects (56,84-86). Crippa et al (66) administered a single-dose of ip ${ }^{131} \mathrm{I}-\mathrm{MOv} 18$ (3700 MBq) to 16 ovarian cancer patients with minimal disease several weeks after second-look evaluation. Tumor response assessed at thirdlook laparotomy indicated a complete response in 5 patients, stable disease in 6 patients and 5 patients with tumor progression. However, this was not a controlled, randomized trial and results should be interpreted with caution.

$\mathrm{OC} / \mathrm{TR}$ is a bispecific Mab that reacts with the folate binding protein on ovarian cancer cells on the one hand and with the CD3 antigen on T-lymphocytes on the other (Table II) (87). The bispecific Mab thus combines the cytolytic potential of in vitro expanded T-lymphocytes and the tumor selectivity of the Mab OC/TR targeting the folate binding protein on ovarian cancer cells (88). The bispecific OC/TR Mab was used to coat the T-lymphocytes in vitro before administration to patients. Bolhuis et al (38) treated 13 ovarian cancer patients with T-lymphocytes retargeted with chimeric OC/TR and administered the Mab-coated T-lymphocytes directly into the peritoneal cavity. Five patients were in complete clinical remission (CCR), 3 had partial regression, 2 had stable disease and 3 patients had progressive disease. Two phase II studies in patients with advanced stage ovarian cancer using retargeted T-lymphocytes with chimeric OC/TR showed antitumor activity in $50 \%$ of the patients $(41,51)$. Further research with OC/TR in combination with retargeted T-lymphocytes showed similar results with local immunomodulation after ip administration in ovarian cancer patients, but without systemic effects (51). In contrast to earlier findings, the development of HAMA was even suggested to be beneficial for survival in patients after ip therapy with OC/TR (27). In 35 patients treated with ip or iv OC/TR, those with progressive disease and HAMA levels of $\geq 150 \mathrm{ng} / \mathrm{ml}$ had a significant higher median survival as compared to patients with progressive disease with HAMA $<150 \mathrm{ng} / \mathrm{ml}$ (27). The effect of HAMA development on survival after therapy with OC/TR treated with T-lymphocytes thus remains controversial.

An overview of trials using Mab directed towards gp38 is shown in Table II. In conclusion, the trials with chimeric OC/TR showed that locoregional immunotherapy with OC/ TR in ovarian cancer may result in tumor regression. However, larger randomized controlled trials should be conducted to confirm these findings.

HER2. HER2, a member of the epidermal growth factor receptor family plays an important role in the deregulation of proliferation of breast and ovarian cancer cells (89). Ovarian tumors that overexpress the proto-oncogene HER2 have a particularly poor survival $(90,91)$. Table III contains an overview of trials using Mab directed towards HER2 in ovarian cancer patients. Trastuzumab also known as Herceptin ${ }^{\circledR}$, is a humanized antibody derived from 4D5, a murine Mab, that recognizes an epitope on the extracellular domain of HER2. This Mab has been approved by the U.S. Food and Drugs Administration (FDA) for the treatment of women with metastatic breast cancer with HER2 overexpression, given either alone or in combination with paclitaxel (92). Only $10 \%$ of the ovarian cancer patients overexpress HER2 on their tumor. Thus, treatment with HER2 antibodies would potentially benefit only a small proportion of patients with epithelial ovarian cancer. The Gynecologic Oncology Group evaluated trastuzumab in a phase I/II trial in patients with recurrent or refractory ovarian cancer overexpressing HER2 (39). A total of 41 patients received iv trastuzumab $(4 \mathrm{mg} / \mathrm{kg})$ with a median treatment of 8 weeks resulting in an overall response rate of $<10 \%$ and a median progression-free interval of 2 months (39). Based on clinical data in breast cancer, the combination of trastuzumab with cytotoxic agents may have a higher impact on survival of patients with minimal residual ovarian cancer (93). Future strategies should focus on the use of the drug in combination with cytotoxic agents.

Pertuzumab is another new antibody directed to the HER2 antigen (Table III) (94). This recombinant humanized monoclonal antibody $2 \mathrm{C} 4$ (IgG) binds to HER2 and is directed against a different epitope than trastuzumab. Pertuzumab inhibits tumor growth after binding by inhibiting ligandactivated HER2 dimerization with HER2 (36). Agus et al (36) performed a phase I study in which patients with solid tumors received iv pertuzumab $(5 \mathrm{mg} / \mathrm{kg})$ every 3 weeks. Three ovarian cancer patients participated in this pilot study of which one had a partial response (36). A phase II openlabel, multicenter study using pertuzumab has been executed in advanced or refractory ovarian cancer patients by Gordon et al (49). They explored two different dosages of iv pertuzumab in 123 patients with recurrent ovarian cancer, resulting in a disappointing low response rate of $4.3 \%$ defined on RECIST criteria (95) and CT scans. The majority of patients had diarrhea as side-effects and $4 \%$ of the patients experienced cardiotoxicity. The results of these two studies did not show any effectiveness of pertuzumab. Recently, a phase II trial in 37 platinum-resistant ovarian cancer patients with repeated administration of the Mab Matuzumab, that binds the ligand-binding portion of the EGFR receptor, did not show any effectiveness as a single agent therapy (55).

MDX-H210 is a bispecific antibody that cross-links the Fc $\gamma$ receptor I on macrophages to the HER2 antigen on tumor cells (Table III) (96). MDX-H210 effectively redirects Fc $\gamma$ receptor I positive effector cells such as monocytes and macrophages to tumor cells that overexpress HER2. Several trials demonstrated that MDX-H210 is well-tolerated and also immunologically active $(96,97)$. De Gramont et al (44) combined monocyte-derived activated killer (MAK) cells with the bispecific Mab MDX-H210 in an attempt to direct the MAK killer effect in patients towards HER2 antigen expressing tumor cells. Patients with HER2 overexpression were treated with MAK cells and Mab MDX-H210 while 
HER2 negative patients only received MAK cells. A total of 8 ovarian cancer patients in CCR with microscopic or macroscopic residual disease after debulking and chemotherapy received MAK cells combined with MDX-H210 (44). Of these 8 patients only 3 remained in CCR, while 4 patients had progressive disease and one patient had stable disease as diagnosed at third-look laparotomy. The full therapeutic potential of MAK cells as consolidation therapy in ovarian cancer is currently being evaluated in a large randomized, comparative trial (44).

In summary, various anti-HER2 antibodies have been used in trials with ovarian cancer patients, however, one should keep in mind that only a minority of ovarian cancers express HER 2 and thus anti-HER2 therapies will only be useful in a small portion of the patients.

MUC1 antigen. In $90 \%$ of the epithelial ovarian tumors the MUC1 antigen is overexpressed on the cell-surface (98). For an overview of anti-MUC1 Mab trials see Table IV. The murine IgG1 monoclonal human milk fat globule 1 (HMFG1) antibody, with specificity to an epitope on the protein backbone of MUC1, was developed by the Imperial Cancer Research Fund. Vaccination with the Mab HMFG1 in ovarian cancer patients was reported by Nicholson et al (58). A phase I trial of 26 ovarian cancer patients receiving a priming dose of $25 \mathrm{mg}$ HMFG1 administered either ip or iv followed by up to 6 intradermal doses of HMFG1 showed that the treatment was safe and well tolerated by patients with induction of an immune response resulting in production of $\mathrm{Ab} 2$ and $\mathrm{Ab} 3$ in some patients (58).

Immunoscintigraphy with radiolabeled HMFG1 and HMFG2, an antibody similar to HMFG1 directed to MUC1, successfully detected MUC1 positive tumors in patients with primary and metastatic lesions of ovarian, breast and gastrointestinal cancer with minor adverse events (99-104). The therapeutic application of radiolabeled HMFG1 in ovarian cancer has been mainly studied following ip administration. In phase I/II trials conducted in the 1990 s with ${ }^{90} \mathrm{Yttrium}-$ labeled HMFG1 (up to $25 \mathrm{mCi}$ per patient) showed that the agent is generally well-tolerated when injected ip $(68,77,105)$. Furthermore, radiolabeled ip HMFG1 induced an immune response resulting in proliferation of T-cells and the production of Ab2 and Ab3 (106-109). Nicholson et al (74) reported that the survival of 25 ovarian cancer patients in CCR who received ${ }^{90} \mathrm{Y}$-HMFG1 $(18 \mathrm{mCi})$ was prolonged compared to matched historical controls with a 5-year survival of respectively 70 vs. $32 \%$. The same conclusions were drawn by Epenetos et al (67) who found a survival rate of $78 \%$ after $>10$ years of follow-up in 21 ovarian cancer patients in CCR who had received a single injection of $25 \mathrm{mg}$ ip ${ }^{90} \mathrm{Y}-\mathrm{HMFG} 1$ (12-32 $\left.\mathrm{mCi}\right)(67)$. Based on these promising results two phase III trials haven been undertaken. The first one by Nicholson et al (75) included 107 ovarian cancer patients in CCR who were randomized between a single ip administration of $25 \mathrm{mg}{ }^{90} \mathrm{Y}-\mathrm{HMFG} 1(30 \mathrm{mCi})$ and standard treatment. With a median follow-up of 40 months, this study was not able to detect any survival advantage in patients treated with ${ }^{90} \mathrm{Y}$-HMFG1. The second phase III study, the Study of MAb RadioimmunoTherapy (SMART) was a multicenter, randomized prospective trial of ip ${ }^{90} \mathrm{Y}-\mathrm{HMFG} 1$
(18-30 mCi, 224 patients) vs. standard treatment (223 control patients) in ovarian cancer patients in CCR (78). Patients were followed for a median time of 3.5 years. This study did not show an improvement in time to relapse or overall survival (78). Reported side-effects of ip HMFG1 were nausea, fatigue, arthralgia, myalgia, thrombocytopenia and neutropenia (78). Although there was no significant difference in time to relapse and overall survival in the SMART study, interestingly, there was a significant difference in pattern of disease recurrence (110). Time to ip relapse was significantly longer in patients that were treated with ip ${ }^{90} \mathrm{Y}-\mathrm{HMFG} 1$, whereas significantly more extraperitoneal relapses were seen in the treatment arm compared to the standard arm (49 vs. 14\%). Most of the extraperitoneal relapses were seen in the lymph nodes $(78 \%)$, the majority of which was situated in the para-aortic region. This observation suggests that ip ${ }^{90} \mathrm{Y}-\mathrm{HMFG} 1$ leads to ip disease control in ovarian cancer patients in CCR (110). Further analysis of the data gathered in the SMART study considering the immune response of participating patients is still ongoing. In the SMART study the HMFG1 dose was relatively high and the radionuclide ${ }^{90} \mathrm{Y}$ may not be the most appropriate for therapy in patients with minimal residual disease. An overview of all discussed trials using Mabs directed towards MUC1 antigen is given in Table IV.

A humanized variant of the murine HMFG1 has been developed and is currently under investigation for breast cancer (www.antisoma.com). This humanized antibody may also be a potential drug for immunotherapy or RIT in ovarian cancer.

Tumor-associated glycoprotein (TAG) 72. The Mab B72.3 targets the tumor-associated glycoprotein, TAG 72 which is expressed on most adenocarcinomas including gastrointestinal and ovarian cancers (111). Research on RIT with ip. B72.3 was done in a phase I trial in which 58 refractory ovarian cancer patients received repeated ip 2-10 mg ${ }^{90} \mathrm{Y}$ B72.3 (5-40 $\mathrm{mCi})$ in combination with calcium disodium versenate (EDTA) (112). In this study the ${ }^{90} \mathrm{Y}$ label was bound in an instable chelate resulting in higher bone uptake of the radionuclide, the rationale of adding EDTA was to investigate the ability of EDTA to suppress the bone uptake of ${ }^{90} \mathrm{Y}$ label and, thus reduce the radiation dose to the bone marrow, preventing myelosuppression. Results of this trial demonstrated the myeloprotective ability of EDTA and clinical responses in four patients.

Further research on the development of new antibodies directed against TAG 72 resulted in a series of secondgeneration antibodies of which CC-49 was selected (Table V). Mab CC49 and Mab B72.3 recognize different epitopes on TAG 72 and CC49 has a 10-fold higher affinity for TAG 72 (113). A phase I trial of $20 \mathrm{mg}$ ip ${ }^{177} \mathrm{Lu}-\mathrm{CC} 49\left(10-30 \mathrm{mCi} / \mathrm{m}^{2}\right)$ in 12 refractory ovarian cancer patients demonstrated good tolerability and even antitumor activity (70). Tumor response as assessed during third-look laparotomy or laparoscopy resulted in one partial response in a patient with gross disease, 6 patients had progressive disease, 4 stable disease and 1 delayed recurrence of disease in patients with microscopic disease (70). Subsequently, Alvarez et al (63) performed a phase I/II trial of $20 \mathrm{mg}$ ip ${ }^{177} \mathrm{Lu}-\mathrm{CC} 49\left(25-45 \mathrm{mCi} / \mathrm{m}^{2}\right)$ in 27 
patients with recurrent ovarian cancer. Follow-up with physical examination and CT scan showed that most patients with gross disease experienced disease progression while prolonged disease-free survival was again seen in patients with microscopic disease. Bone marrow toxicity was noted as the dose-limiting effect of ${ }^{177} \mathrm{Lu}-\mathrm{CC} 49$ (63). Meredith et al (71) administered ip ${ }^{177} \mathrm{Lu}-\mathrm{CC} 49\left(40-45 \mathrm{mCi} / \mathrm{m}^{2}\right)$ in combination with interferon $\alpha(\operatorname{IFN} \alpha)$ and paclitaxel in patients with recurrent or persistent ovarian cancer. This combined strategy was based on the findings that IFN $\alpha$ enhanced the expression of TAG 72 tumor antigen and improves localization of radiolabeled antibody in the tumor (114). The study of Meredith et al (71) led to partial responses in 4 of the 17 treated patients and stable disease in 4 out of 27 patients without measurable disease, assessed during third-look laparotomy or laparoscopy. A combination of ip. $20 \mathrm{mg}{ }^{90} \mathrm{Y}-\mathrm{CC} 49\left(14-24.2 \mathrm{mCi} / \mathrm{m}^{2}\right)$, subcutaneous IFN $\alpha 2 b$ and ip paclitaxel in 20 persistent or recurrent ovarian cancer patients showed good feasibility and was welltolerated (64). Tumor response as assessed with CT scan during follow-up revealed a partial response in 2 patients with measurable disease. Out of the patients with non-measurable disease, 4 patients remained disease-free of which 3 longer than 18 months (64). The combination of ip. ${ }^{90} \mathrm{Y}-\mathrm{CC} 49$ with chemotherapy seems to be well-tolerated, but larger prospective and randomized trials are needed to demonstrate whether this therapy is effective.

$V E G F$. Vascular endothelial growth factor (VEGF) is a mediator of angiogenesis and is expressed in most ovarian cancers (115). Bevacizumab is a humanized antibody directed against VEGF (overview of trials in Table VI) $(116,117)$. A well characterized activity of VEGF is to promote the growth of vascular endothelial cells. Bevacizumab binds all 5 isoforms of VEGF, which prevent interaction with the VEGF receptors. Binding of bevacizumab inhibits formation of new blood vessels and a decrease in vessel diameter, density and permeability. This results in normalization of tumor vasculature $(116,117)$. Through this mechanism, bevacizumab might increase the delivery of drugs $(116,117)$. Trials investigating bevacizumab as monotherapy failed to prove effectiveness. However, randomized trials in breast, colon and lung cancers have shown that the addition of bevacizumab to standard chemotherapeutic regimens results in statistically significant improvements in both progressionfree and overall survival (7). In 2004 the FDA approved the use of bevacizumab as adjuvant therapy with 5-fluorouracilbased chemotherapy in advanced stage colorectal cancer. In October 2006, bevacizumab was also approved by the FDA for the treatment of advanced lung cancer in conjunction with paclitaxel and carboplatin-based chemotherapy. These approvals established the therapeutic potential of anti-angiogenesis treatments. The pathobiology of ovarian cancer and its ip metastatic spread is similar to metastatic colorectal cancer and suggests that ovarian cancer may also be amenable to anti-angiogenic intervention. Cannistra et al (42) investigated the single-agent activity of bevacizumab $(15 \mathrm{mg} / \mathrm{kg})$ in 44 platinum-resistant heavily pre-treated ovarian cancer patients. Seven of the 44 patients had a partial response, as defined on RECIST guidelines (95), with a progression-free survival (PFS) at 4.3 months for all patients. The Gynecologic Oncology Group (GOG 170-D trial) assessed the response rates and 6-month progression-free survival (PFS) of iv bevacizumab $(15 \mathrm{mg} / \mathrm{kg})$ three-weekly in a cohort of 62 refractory or recurrent ovarian cancer patients (40). Three patients were in complete clinical remission, 8 patients had partial remission, 34 patients had stable disease and 17 patients had progressive disease. In $38.7 \%$ of the patients there was stable disease for $>6$ months. Cohn et al (43) treated 10 ovarian cancer patients with a combination of weekly taxane and biweekly bevacizumab $(10 \mathrm{mg} / \mathrm{kg})$ therapy, which led to temporarily improvement on cancer-related symptoms (e.g. diminishing ascites, lowering CA 125 levels) without toxicity. Monk et al (53) found similar results in 32 refractory ovarian cancer patients treated with the same combination therapy (bevacizumab $15 \mathrm{mg} / \mathrm{kg}$ ) resulting in one complete remission, 4 partial responses and in $62 \%$ of the patients stable disease (disease progression was defined on RECIST guidelines) (95).

A combination of oral cyclophosphamide and bevacizumab $(10 \mathrm{mg} / \mathrm{kg})$ in 29 recurrent ovarian cancer patients resulted in 6 partial responses, 17 patients with stable disease and 6 with disease progression. About $47 \%$ of the patients had stable disease at 6 months (47). A retrospective analysis with different bevacizumab doses in combination with cytotoxic chemotherapeutic agents in 23 recurrent or refractory ovarian cancer patients showed similar results, with partial remissions in $35 \%$, stable disease in $44 \%$ and a PFS of 6 months in $13 \%$ of the patients (57). These results with bevacizumab in combination with cytotoxic therapy are promising as additional therapy to standard treatment for ovarian cancer and warrant further investigation. Two phase III trials in front-line ovarian cancer therapy are currently in progress (118).

\section{Conclusion}

In contrast to hematological malignancies and certain solid malignancies (breast, colorectal and lung), Mab-based therapy modalities have not yet convincingly proven to be efficacious in the treatment of ovarian cancer. Antibodies are multifunctional molecules that can target tumor cells, stimulate the immune system to attack tumor cells and engage receptor pathways effective in tumor cell destruction.

Of the discussed Mabs, oregovomab directed to the CA 125 antigen and bevacizumab targeting VEGF are two unconjugated Mabs closest to potential clinical introduction for the treatment of ovarian cancer. Oregovomab has proven to be effective in large trials with patients with recurrent disease or as consolidation strategy. Anti-VEGF Mabs in combination with chemotherapy has proven to be effective in other malignancies and the initial trials of this combination in ovarian cancer patients show similar results.

Considering the reviewed vaccination regimens, vaccination with the Mab ACA 125 inducing the production of anti-tumor antibodies seems promising, but further research in controlled randomized trials should be performed to affirm these findings.

Sole RIT should be investigated with the appropriate radionuclide in combination with Mabs with high affinity for the tumor-associated antigen in the appropriate group 
of patients to see whether it may have effect. Additionally, appending RIT with CC49 or HMFG1 to other treatment strategies such as chemotherapy or lymphadenectomy could also be a strategy worthwhile investigating. Ip RIT seems to be effective for local disease control and this should be the administration route of preference. However controlled randomized trials still need to affirm these treatment modalities.

The lack of large randomized prospective trials with the specific Mabs preclude any firm conclusion on the potential of Mabs use in the treatment of ovarian cancer although several antibodies have shown to induce significant humoral and cellular immune responses with anti-tumor activity. The potential of Mabs to complement current treatment in ovarian cancer is encouraging and may bring a significant improvement to the overall therapeutic outcomes currently being achieved in this disease.

\section{References}

1. Brewer MA, Johnson K, Follen M, Gershenson D and Bast R Jr: Prevention of ovarian cancer: intraepithelial neoplasia. Clin Cancer Res 9: 20-30, 2003.

2. Cannistra SA: Cancer of the ovary. N Engl J Med 351: 2519-2529, 2004.

3. Jemal A, Siegel R, Ward E, Murray T, Xu J and Thun MJ: Cancer statistics, 2007. CA Cancer J Clin 57: 43-66, 2007.

4. Heintz AP, Odicino F, Maisonneuve P, et al: Carcinoma of the ovary. Int J Gynaecol Obstet 83 (Suppl. 1): 135-166, 2003.

5. Grillo-Lopez AJ, Hedrick E, Rashford M and Benyunes M: Rituximab: ongoing and future clinical development. Semin Oncol 29: 105-112, 2002.

6. Uppenkamp M, Engert A, Diehl V, Bunjes D, Huhn D and Brittinger G: Monoclonal antibody therapy with CAMPATH$1 \mathrm{H}$ in patients with relapsed high- and low-grade non-Hodgkin's lymphomas: a multicenter phase I/II study. Ann Hematol 81: 26-32, 2002.

7. Hurwitz H, Fehrenbacher L, Novotny W, et al: Bevacizumab plus irinotecan, fluorouracil and leucovorin for metastatic colorectal cancer. N Engl J Med 350: 2335-2342, 2004.

8. Kabbinavar F, Hurwitz HI, Fehrenbacher L, et al: Phase II, randomized trial comparing bevacizumab plus fluorouracil (FU)/leucovorin (LV) with FU/LV alone in patients with metastatic colorectal cancer. J Clin Oncol 21: 60-65, 2003.

9. Saltz LB, Meropol NJ, Loehrer PJ Sr, Needle MN, Kopit J and Mayer RJ: Phase II trial of cetuximab in patients with refractory colorectal cancer that expresses the epidermal growth factor receptor. J Clin Oncol 22: 1201-1208, 2004.

10. Gura T: Therapeutic antibodies: magic bullets hit the target. Nature 417: 584-586, 2002.

11. Ehrlich P: Collected Studies on Immunology. John Wiley, New York, 1906.

12. Kohler G and Milstein C: Continuous cultures of fused cells secreting antibody of predefined specificity. Nature 256: 495-497, 1975 .

13. Linenberger ML, Maloney DG and Bernstein ID: Antibodydirected therapies for hematological malignancies. Trends Mol Med 8: 69-76, 2002.

14. Yokota T, Milenic DE, Whitlow M and Schlom J: Rapid tumor penetration of a single-chain Fv and comparison with other immunoglobulin forms. Cancer Res 52: 3402-3408, 1992.

15. Goldenberg DM: Targeted therapy of cancer with radiolabeled antibodies. J Nucl Med 43: 693-713, 2002.

16. Yokota T, Milenic DE, Whitlow M, Wood JF, Hubert SL and Schlom J: Microautoradiographic analysis of the normal organ distribution of radioiodinated single-chain Fv and other immunoglobulin forms. Cancer Res 53: 3776-3783, 1993.

17. Iannello A and Ahmad A: Role of antibody-dependent cellmediated cytotoxicity in the efficacy of therapeutic anti-cancer monoclonal antibodies. Cancer Metastasis Rev 24: 487-499, 2005.

18. Herlyn D, Ross AH and Koprowski H: Anti-idiotypic antibodies bear the internal image of a human tumor antigen. Science 232: 100-102, 1986.

19. Jerne NK: Towards a network theory of the immune system. Ann Immunol 125C: 373-389, 1974.
20. De Nardo GL, Bradt BM, Mirick GR and De Nardo SJ: Human antiglobulin response to foreign antibodies: therapeutic benefit? Cancer Immunol Immunother 52: 309-316, 2003.

21. Khazaeli MB, Conry RM and Lo Buglio AF: Human immune response to monoclonal antibodies. J Immunother Emphasis Tumor Immunol 15: 42-52, 1994.

22. Van Kroonenburgh MJ and Pauwels EK: Human immunological response to mouse monoclonal antibodies in the treatment or diagnosis of malignant diseases. Nucl Med Commun 9: 919-930, 1988.

23. Kricka LJ: Human anti-animal antibody interferences in immunological assays. Clin Chem 45: 942-956, 1999.

24. Klee GG: Human anti-mouse antibodies. Arch Pathol Lab Med 124: 921-923, 2000.

25. Azinovic I, De Nardo GL, Lamborn KR, et al: Survival benefit associated with human anti-mouse antibody (HAMA) in patients with B-cell malignancies. Cancer Immunol Immunother 55: 1451-1458, 2006.

26. Fagerberg J, Ragnhammar P, Liljefors M, Hjelm AL, Mellstedt H and Frodin JE: Humoral anti-idiotypic and anti-anti-idiotypic immune response in cancer patients treated with monoclonal antibody 17-1A. Cancer Immunol Immunother 42: 81-87, 1996.

27. Miotti S, Negri DR, Valota O, et al: Level of anti-mouseantibody response induced by bi-specific monoclonal antibody OC/TR in ovarian-carcinoma patients is associated with longer survival. Int J Cancer 84: 62-68, 1999.

28. Wagner UA, Oehr PF, Reinsberg J, et al: Immunotherapy of advanced ovarian carcinomas by activation of the idiotypic network. Biotechnol Ther 3: 81-89, 1992.

29. Morrison SL, Johnson MJ, Herzenberg LA and Oi VT: Chimeric human antibody molecules: mouse antigen-binding domains with human constant region domains. Proc Natl Acad Sci USA 81: 6851-6855, 1984.

30. Green LL, Hardy MC, Maynard-Currie CE, et al: Antigenspecific human monoclonal antibodies from mice engineered with human Ig heavy and light chain YACs. Nat Genet 7: 13-21, 1994.

31. Wagner SD, Williams GT, Larson T, et al: Antibodies generated from human immunoglobulin miniloci in transgenic mice. Nucleic Acids Res 22: 1389-1393, 1994.

32. Dillman RO, Beauregard JC, Halpern SE and Clutter M: Toxicities and side effects associated with intravenous infusions of murine monoclonal antibodies. J Biol Response Mod 5: 73-84, 1986

33. Frodin JE, Lefvert AK and Mellstedt H: The clinical significance of HAMA in patients treated with mouse monoclonal antibodies. Cell Biophys 21: 153-165, 1992.

34. Kimby E: Tolerability and safety of rituximab. (MabThera) Cancer Treat Rev 31: 456-473, 2005.

35. Murray JL, Cunningham JE, Brewer $\mathrm{H}$, et al: Phase I trial of murine monoclonal antibody $14 \mathrm{G} 2 \mathrm{a}$ administered by prolonged intravenous infusion in patients with neuroectodermal tumors. J Clin Oncol 12: 184-193, 1994.

36. Agus DB, Gordon MS, Taylor C, et al: Phase I clinical study of pertuzumab, a novel HER dimerization inhibitor, in patients with advanced cancer. J Clin Oncol 23: 2534-2543, 2005.

37. Berek JS, Taylor PT, Gordon A, et al: Randomized, placebocontrolled study of oregovomab for consolidation of clinical remission in patients with advanced ovarian cancer. J Clin Oncol 22: 3507-3516, 2004.

38. Bolhuis RL, Lamers CH, Goey SH, et al: Adoptive immunotherapy of ovarian carcinoma with bs-MAb-targeted lymphocytes: a multicenter study. Int J Cancer (Suppl) 7: 78-81, 1992.

39. Bookman MA, Darcy KM, Clarke-Pearson D, Boothby RA and Horowitz IR: Evaluation of monoclonal humanized anti-HER2 antibody, trastuzumab, in patients with recurrent or refractory ovarian or primary peritoneal carcinoma with overexpression of HER2: a phase II trial of the Gynecologic Oncology Group. J Clin Oncol 21: 283-290, 2003.

40. Burger RA, Sill M, Monk BJ, Greer B and Sorosky J: Phase II trial of bevacizumab in persistent or recurrent epithelial ovarian cancer (EOC) or primary peritoneal cancer (PPC): a Gynecologic Oncology Group (GOG) study. J Clin Oncol 23: 457s (suppl) abs 5009, 2005.

41. Canevari S, Stoter G, Arienti F, et al: Regression of advanced ovarian carcinoma by intraperitoneal treatment with autologous $\mathrm{T}$ lymphocytes retargeted by a bispecific monoclonal antibody. J Natl Cancer Inst 87: 1463-1469, 1995. 
42. Cannistra SA, Matulonis UA, Penson R, Wenham R, Armstrong $\mathrm{R}$ and Burger RA: bevacizumab in patients with advanced platinum-resistant ovarian cancer. J Clin Oncol 24: 18S (suppl) abs 5006, 2006.

43. Cohn DE, Valmadre S, Resnick KE, Eaton LA, Copeland LJ and Fowler JM: Bevacizumab and weekly taxane chemotherapy demonstrates activity in refractory ovarian cancer. Gynecol Oncol 102: 134-139, 2006.

44. De Gramont GA, Gangji D, Louvet C, Garcia ML, Tardy D and Romet-Lemonne JL: Adoptive immunotherapy of ovarian carcinoma. Gynecol Oncol 86: 102-103, 2002.

45. Ehlen TG, Gordon AN, Fingert HJ, Nicodemus CF, Schultes B and Whiteside TL: Adjuvant treatment with monoclinal antibody, OvaRex MAb-43.13 (OV) targeting CA 125, induces robust immune responses associated with prolonged time to relapse in a randomized controlled study in patients with advanced epithelial ovarian cancer (EOC). J Clin Oncol ASCO, abs 31, 2002.

46. Ehlen TG, Hoskins PJ, Miller D, et al: A pilot phase 2 study of oregovomab murine monoclonal antibody to CA125 as an immunotherapeutic agent for recurrent ovarian cancer. Int $\mathbf{J}$ Gynecol Cancer 15: 1023-1034, 2005.

47. Garcia AA, Oza AM, Hirte H, et al: Interim report of a phase II clinical trial of bevacizumab (Bev) and low dose metronomic oral cyclophosphamide (mCTX) in recurrent ovarian (OC) and primary peritoneal carcinoma: a California Cancer Consortium Trial. J Clin Oncol 23: 16s (suppl) abs 5000, 2005.

48. Gordon AN, Schultes BC, Gallion H, et al: CA 125 and tumorspecific T-cell response correlate with prolonged survival in oregovomab-treated recurrent ovarian cancer patients. Gynecol Oncol 94: 340-351, 2004.

49. Gordon MS, Matei D, Aghajanian C, et al: Clinical activity of pertuzumab (rhuMAb 2C4), a HER dimerization inhibitor, in advanced ovarian cancer: potential predictive relationship with tumor HER2 activation status. J Clin Oncol 24: 4324-4332, 2006.

50. Lamers CH, Gratama JW, Warnaar SO, Stoter G and Bolhuis RL: Inhibition of bispecific monoclonal antibody (bsAb)-targeted cytolysis by human anti-mouse antibodies in ovarian carcinoma patients treated with bsAb-targeted activated T-lymphocytes. Int J Cancer 60: 450-457, 1995.

51. Lamers CH, Bolhuis RL, Warnaar SO, Stoter G and Gratama JW: Local but no systemic immunomodulation by intraperitoneal treatment of advanced ovarian cancer with autologous T lymphocytes re-targeted by a bi-specific monoclonal antibody. Int $\mathrm{J}$ Cancer 73: 211-219, 1997.

52. Method MW, Gordon AN, Finkler N, Cieszynski J and Nicodemus CF: Final analysis of a randomized dosing study of oregovomab in patients with advanced ovarian cancer. J Clin Oncol 23: 16S (suppl) abs 5035, 2005.

53. Monk BJ, Han E, Josephs-Cowan CA, Pugmire G and Burger RA: Salvage bevacizumab (rhuMAB VEGF)-based therapy after multiple prior cytotoxic regimens in advanced refractory epithelial ovarian cancer. Gynecol Oncol 102: 140-144, 2006.

54. Schultes BC, Baum RP, Niesen A, Noujaim AA and Madiyalakan R: Anti-idiotype induction therapy: anti-CA 125 antibodies (Ab3) mediated tumor killing in patients treated with Ovarex mAb B43.13 (Ab1). Cancer Immunol Immunother 46: 201-212, 1998.

55. Seiden MV, Burris HA, Matulonis U, et al: A phase II trial of EMD72000 (matuzumab), a humanized anti-EGFR monoclonal antibody, in patients with platinum-resistant ovarian and primary peritoneal malignancies. Gynecol Oncol 104: 727-731, 2007.

56. Van Zanten-Przybysz I, Molthoff C, Gebbinck JK, et al: Cellular and humoral responses after multiple injections of unconjugated chimeric monoclonal antibody MOv18 in ovarian cancer patients: a pilot study. J Cancer Res Clin Oncol 128: 484-492, 2002.

57. Wright JD, Hagemann A, Rader JS, et al: Bevacizumab combination therapy in recurrent, platinum-refractory, epithelial ovarian carcinoma: a retrospective analysis. Cancer 107: 83-89, 2006.

58. Nicholson S, Bomphray CC, Thomas H, et al: A phase I trial of idiotypic vaccination with HMFG1 in ovarian cancer. Cancer Immunol Immunother 53: 809-816, 2004.

59. Reinartz S, Kohler S, Schlebusch H, et al: Vaccination of patients with advanced ovarian carcinoma with the anti-idiotype ACA125: immunological response and survival (phase Ib/II). Clin Cancer Res 10: 1580-1587, 2004.
60. Wagner U, Schlebusch H, Kohler S, Schmolling J, Grunn U and Krebs D: Immunological responses to the tumor-associated antigen CA125 in patients with advanced ovarian cancer induced by the murine monoclonal anti-idiotype vaccine ACA 125 . Hybridoma 16: 33-40, 1997.

61. Wagner U, Kohler S, Reinartz S, et al: Immunological consolidation of ovarian carcinoma recurrences with monoclonal anti-idiotype antibody ACA 125: immune responses and survival in palliative treatment. Clin Cancer Res 7: 1154-1162, 2001.

62. Pfisterer J, Du BA, Sehouli J, et al: The anti-idiotypic antibody abagovomab in patients with recurrent ovarian cancer. a phase I trial of the AGO-OVAR. Ann Oncol 17: 15681577,2006

63. Alvarez RD, Partridge EE, Khazaeli MB, et al: Intraperitoneal radioimmunotherapy of ovarian cancer with 177Lu-CC49: a phase I/II study. Gynecol Oncol 65: 94-101, 1997.

64. Alvarez RD, Huh WK, Khazaeli MB, et al: A Phase I study of combined modality (90)Yttrium-CC49 intraperitoneal radioimmunotherapy for ovarian cancer. Clin Cancer Res 8: 2806-2811, 2002 .

65. Baum RP, Niesen A, Hertel A, et al: Activating anti-idiotypic human anti-mouse antibodies for immunotherapy of ovarian carcinoma. Cancer 73: 1121-1125, 1994.

66. Crippa F, Bolis G, Seregni E, et al: Single-dose intraperitoneal radioimmunotherapy with the murine monoclonal antibody I-131 MOv18: clinical results in patients with minimal residual disease of ovarian cancer. Eur J Cancer 31A: 686-690, 1995.

67. Epenetos AA, Hird V, Lambert H, Mason P and Coulter C: Long-term survival of patients with advanced ovarian cancer treated with intraperitoneal radioimmunotherapy. Int J Gynecol Cancer 10: 44-46, 2000.

68. Hird V, Maraveyas A, Snook D, et al: Adjuvant therapy of ovarian cancer with radioactive monoclonal antibody. Br J Cancer 68: 403-406, 1993.

69. Mahe MA, Fumoleau P, Fabbro M, et al: A phase II study of intraperitoneal radioimmunotherapy with iodine-131-labeled monoclonal antibody OC-125 in patients with residual ovarian carcinoma. Clin Cancer Res 5: S3249-S3253, 1999.

70. Meredith RF, Partridge EE, Alvarez RD, et al: Intraperitoneal radioimmunotherapy of ovarian cancer with lutetium-177CC49. J Nucl Med 37: 1491-1496, 1996.

71. Meredith RF, Alvarez RD, Partridge EE, et al: Intraperitoneal radioimmunochemotherapy of ovarian cancer: a phase I study. Cancer Biother Radiopharm 16: 305-315, 2001.

72. Mobus VJ, Baum RP, Bolle M, et al: Immune responses to murine monoclonal antibody-B43.13 correlate with prolonged survival of women with recurrent ovarian cancer. Am J Obstet Gynecol 189: 28-36, 2003.

73. Muto MG, Finkler NJ, Kassis AI, et al: Intraperitoneal radioimmunotherapy of refractory ovarian carcinoma utilizing iodine-131-labeled monoclonal antibody OC125. Gynecol Oncol 45: 265-272, 1992.

74. Nicholson S, Gooden CS, Hird V, et al: Radioimmunotherapy after chemotherapy compared to chemotherapy alone in the treatment of advanced ovarian cancer: a matched analysis. Oncol Rep 5: 223-226, 1998.

75. Nicholson S, Bell S, McCormack M, Bomphray CC, Ganesan T and Gore M: A randomised phase III trial of adjuvant intraperitoneal radioimmunotherapy in ovarian cancer. J Clin Oncol ASCO, abs 1514, 2000.

76. Rosenblum MG, Verschraegen CF, Murray JL, et al: Phase I study of 90Y-labeled B72.3 intraperitoneal administration in patients with ovarian cancer: effect of dose and EDTA coadministration on pharmacokinetics and toxicity. Clin Cancer Res 5: 953-961, 1999.

77. Stewart JS, Hird V, Snook D, et al: Intraperitoneal yttrium-90labeled monoclonal antibody in ovarian cancer. J Clin Oncol 8: 1941-1950, 1990.

78. Verheijen RH, Massuger LF, Benigno BB, et al: Phase III trial of intraperitoneal therapy with yttrium-90-labeled HMFG1 murine monoclonal antibody in patients with epithelial ovarian cancer after a surgically defined complete remission. J Clin Oncol 24: 571-578, 2006.

79. Van Zanten-Przybysz I, Molthoff CF, Roos JC, et al: Radioimmunotherapy with intravenously administered ${ }^{131}$ I-labeled chimeric monoclonal antibody MOv18 in patients with ovarian cancer. J Nucl Med 41: 1168-1176, 2000. 
80. Madiyalakan R, Sykes TR, Dharampaul S, et al: Antiidiotype induction therapy: evidence for the induction of immune response through the idiotype network in patients with ovarian cancer after administration of anti-CA125 murine monoclonal antibody B43.13. Hybridoma 14: 199-203, 1995.

81. Noujaim AA, Schultes BC, Baum RP and Madiyalakan R: Induction of CA125-specific B and $\mathrm{T}$ cell responses in patients injected with MAb-B43.13-evidence for antibody-mediated antigen-processing and presentation of CA125 in vivo. Cancer Biother Radiopharm 16: 187-203, 2001.

82. Wagner U: Antitumor antibodies for immunotherapy of ovarian carcinomas. Hybridoma 12: 521-528, 1993.

83. Miotti S, Canevari S, Menard S, et al: Characterization of human ovarian carcinoma-associated antigens defined by novel monoclonal antibodies with tumor-restricted specificity. Int J Cancer 39: 297-303, 1987.

84. Buijs WC, Tibben JG, Boerman OC, et al: Dosimetric analysis of chimeric monoclonal antibody cMOv $18 \mathrm{IgG}$ in ovarian carcinoma patients after intraperitoneal and intravenous administration. Eur J Nucl Med 25: 1552-1561, 1998.

85. Molthoff CF, Prinssen HM, Kenemans P, van Hof AC, Den HW and Verheijen RH: Escalating protein doses of chimeric mono-clonal antibody MOv18 immunoglobulin G in ovarian carcinoma patients: a phase I study. Cancer 80: 2712-2720, 1997.

86. Van Zanten-Przybysz I, Molthoff CF, Roos JC, et al: Influence of the route of administration on targeting of ovarian cancer with the chimeric monoclonal antibody MOv18: iv. vs. ip. Int J Cancer 92: 106-114, 2001.

87. Tibben JG, Boerman OC, Massuger LF, Schijf CP Claessens RA and Corstens FH: Pharmacokinetics, biodistribution and biological effects of intravenously admi-nistered bispecific monoclonal antibody $\mathrm{OC} / \mathrm{TR} \mathrm{F}\left(\mathrm{ab}^{\prime}\right) 2$ in ovarian carcinoma patients. Int J Cancer 66: 477-483, 1996.

88. Van Dijk J, Warnaar SO, van Eendenburg JD, et al: Induction of tumor-cell lysis by bi-specific monoclonal antibodies recognizing renal-cell carcinoma and $\mathrm{CD} 3$ antigen. Int J Cancer 43: 344-349, 1989.

89. Legge F, Ferrandina G, Salutari V and Scambia G: Biological characterization of ovarian cancer: prognostic and therapeutic implications. Ann Oncol 16 (Suppl 4): iv95-iv101, 2005.

90. Berchuck A, Elbendary A, Havrilesky L, Rodriguez GC and Bast RC Jr: Pathogenesis of ovarian cancers. J Soc Gynecol Investig 1: 181-190, 1994

91. Camilleri-Broet S, Hardy-Bessard AC, Le TA, et al: HER-2 overexpression is an independent marker of poor prognosis of advanced primary ovarian carcinoma: a multicenter study of the GINECO group. Ann Oncol 15: 104-112, 2004.

92. Brand FX, Ravanel N, Gauchez AS, et al: Prospect for anti-her2 receptor therapy in breast cancer. Anticancer Res 26: 715-722, 2006.

93. Ocana A, Hortobagyi GN and Esteva FJ: Concomitant versus sequential chemotherapy in the treatment of early-stage and metastatic breast cancer. Clin Breast Cancer 6: 495-504, 2006.

94. Adams CW, Allison DE, Flagella K, et al: Humanization of a recombinant monoclonal antibody to produce a therapeutic HER dimerization inhibitor, pertuzumab. Cancer Immunol Immunother 55: 717-727, 2006.

95. Therasse P, Arbuck SG, Eisenhauer EA, et al: New guidelines to evaluate the response to treatment in solid tumors. European Organization for Research and Treatment of Cancer, National Cancer Institute of the United States, National Cancer Institute of Canada. J Natl Cancer Inst 92: 205-216, 2000

96. Valone FH, Kaufman PA, Guyre PM, et al: Phase Ia/Ib trial of bispecific antibody MDX-210 in patients with advanced breast or ovarian cancer that overexpresses the proto-oncogene HER-2/neu. J Clin Oncol 13: 2281-2292, 1995.

97. Valone FH, Kaufman PA, Guyre PM, et al: Clinical trials of bispecific antibody MDX-210 in women with advanced breast or ovarian cancer that overexpresses HER-2/neu. J Hematother 4: 471-475, 1995

98. Taylor-Papadimitriou J, Peterson JA, Arklie J, Burchell J, Ceriani RL and Bodmer WF: Monoclonal antibodies to epithelium-specific components of the human milk fat globule membrane: production and reaction with cells in culture. Int J Cancer 28: 17-21, 1981.
99. Epenetos AA, Britton KE, Mather S, et al: Targeting of iodine123-labelled tumour-associated monoclonal antibodies to ovarian, breast, and gastrointestinal tumours. Lancet 2: 999-1005, 1982.

100. Granowska M, Britton KE, Shepherd JH, et al: A prospective study of 123I-labeled monoclonal antibody imaging in ovarian cancer. J Clin Oncol 4: 730-736, 1986.

101. Kosmas C, Kalofonos HP and Epenetos AA: Radiolabelled monoclonal antibodies in tumour diagnosis and therapy. Dev Biol Stand 71: 93-102, 1990.

102. Malamitsi J, Skarlos D, Fotiou S, et al: Intracavitary use of two radiolabeled tumor-associated monoclonal antibodies. J Nucl Med 29: 1910-1915, 1988

103. Pectasides D, Pateniotis K, Tzimis L, et al: Immunoscintigraphy with 131I-labelled monoclonal antibodies HMFG2 and HMFG1 $\mathrm{F}\left(\mathrm{ab}^{\prime}\right) 2$ versus abdominal $\mathrm{CT}$ scan in the detection of residual disease in ovarian cancer patients. Int J Cancer (Suppl) 3: 8388, 1988.

104. Rosner D, Nabi H, Wild L, Ortman-Nabi J and Hreshchyshyn MM: Diagnosis of breast carcinoma with radiolabeled monoclonal antibodies (MoAbs) to carcinoembryonic antigen (CEA) and human milk fat globulin (HMFG). Cancer Invest 13: 573-582, 1995.

105. Maraveyas A, Snook D, Hird V, et al: Pharmacokinetics and toxicity of an yttrium-90-CITC-DTPA-HMFG1 radioimmunoconjugate for intraperitoneal radioimmunotherapy of ovarian cancer. Cancer 73: 1067-1075, 1994.

106. Courtenay-Luck NS, Epenetos AA, Moore R, et al: Development of primary and secondary immune responses to mouse monoclonal antibodies used in the diagnosis and therapy of malignant neoplasms. Cancer Res 46: 6489-6493, 1986.

107. Kosmas C, Man S, Epenetos AA and Courtenay-Luck NS: The role of humoral and cellular immunity in patients developing human anti-murine immunoglobulin antibody responses after radioimmunotherapy. Br J Cancer (Suppl) 10: 85-88, 1990

108. Kosmas C, Epenetos AA and Courtenay-Luck NS: Patients receiving murine monoclonal antibody therapy for malignancy develop $\mathrm{T}$ cells that proliferate in vitro in response to these antibodies as antigens. Br J Cancer 64: 494-500, 1991.

109. Kosmas C, Epenetos AA and Courtenay-Luck NS: Activation of cellular immunity after intracavitary monoclonal antibody therapy of ovarian cancer. Cancer 73: 3000-3010, 1994.

110. Oei AL, Verheijen RH, Seiden MV, et al: Decreased intraperitoneal disease recurrence in epithelial ovarian cancer patients receiving intraperitoneal consolidation treatment with yttrium90-labeled murine HMFG1 without improvement in overall survival. Int J Cancer 120: 2710-2714, 2007.

111. Rosenblum MG, Kavanagh JJ, Burke TW et al: Clinical pharmacology, metabolism, and tissue distribution of 90Ylabeled monoclonal antibody B72.3 after intraperitoneal administration. J Natl Cancer Inst 83: 1629-1636, 1991.

112. Krag DN, Ford P, Smith L, et al: Clinical immunoscintigraphy of recurrent ovarian cancer with indium 111-labeled B72.3 monoclonal antibody. Arch Surg 128: 819-823, 1993.

113. Kuroki M, Fernsten PD, Wunderlich D, et al: Serological mapping of the TAG-72 tumor-associated antigen using 19 distinct monoclonal antibodies. Cancer Res 50: 4872-4879, 1990.

114. Roselli M, Guadagni F, Buonomo O, et al: Systemic administration of recombinant interferon alfa in carcinoma patients upregulates the expression of the carcinoma-associated antigens tumor-associated glycoprotein-72 and carcino-embryonic antigen. J Clin Oncol 14: 2031-2042, 1996.

115. Leung DW, Cachianes G, Kuang WJ, Goeddel DV and Ferrara N Vascular endothelial growth factor is a secreted angiogenic mitogen. Science 246: 1306-1309, 1989.

116. Jain RK: Normalizing tumor vasculature with anti-angiogenic therapy: a new paradigm for combination therapy. Nat Med 7: 987-989, 2001

117. Jain RK: Normalization of tumor vasculature: an emerging concept in antiangiogenic therapy. Science 307: 58-62, 2005.

118. Burger RA: Experience with bevacizumab in the management of epithelial ovarian cancer. J Clin Oncol 25: 2902-2908, 2007. 